\title{
STUDY OF PARENTING PATTERN, CHILDHOOD SEXUAL VIOLENCE TRAUMA, PERSONAL KNOWLEDGE, SOCIAL AGENTS ROLE, AND GOVERNMENT INTERVENTIONS ON HOMOSEKSUAL (GAY) TENDENCIES (PERSPECTIVE: SOCIAL MARKETING)
}

\begin{abstract}
Rina Astini
Universitas Mercu Buana, Jakarta Indonesia

ABSTRACT

Homosexual phenomenon as an unusual thing in social relations leads to the pros cons, especially in the state of Indonesia that highly upholds Pancasila and Religion as the basic guidance of attitude and state. In the midst of increasing resistance to the existence of LGBT in Indonesia, the number of homosexual or LGBT tendencies has increased significantly. This study was conducted to analyze the factors that influence or not affect the tendency of a person to behave homosexual, in this case studied is gay behavior. Some of the factors studied are parental parenting, childhood sexual violence trauma, personal knowledge, the role of social agents and government intervention. The sample of the study was respondents who indicated gay behavior who lived in some areas in Jakarta as many as 220 respondents. The research analysis used SEM analysis using LISREL 8.5 program. The results of this study indicate that personal knowledge about good to be gay and social agents role (parents, family, friends, public figures / celebrities, etc.) affects a person's tendency to behave gay. Meanwhile, parental parenting, childhood sexual violence trauma, and government intervention do not affect a person's tendency to behave gay.
\end{abstract}

Keywords: Parental parenting, childhood sexual violence trauma, personal knowledge, social agent role, government intervention, homosexual / gay, homosexual, gay, LGBT

DOI: $10.7176 / \mathrm{JMCR} / 53-07$

\section{INTRODUCTION}

Homosexuality is sexual attraction towards the same sex (Feldmen, 2011). Homosexuality is not just sexual contact between a person and another of the same sex but also concerns an individual with a psychological, emotional, and social tendency toward a person of the same sex (Kendall \& Hammer, in Nugroho, Siswati, \& Sakti 2012). Simply put, homosexuality can be interpreted as a strong tendency of one's erotic attractiveness to the same sex. The term homosexual is more commonly used for men who suffer from this deviation, while for women, the same condition is more commonly called "lesbian" (Sadarjoen, 2005). Homosexuality itself consists of two classes, namely lesbian and gay. A lesbian is a woman who satisfies her lover with same sex; homosexual woman (Rahman, 2013). While gays are men who love men either physically, sexually, emotionally, or spiritually. The average homosexual is quite concerned about appearance, and very concerned about what happened to his partner (Ilham, 2012).

Homosexual phenomenon as an unusual thing in social relations leads to the pros cons, especially in the state of Indonesia that highly upholds Pancasila and Religion as the basic guidance of attitude and state. Negative responses emerge against the existence of homosexuals, especially homosexuals in Indonesia, even from year to year the rejection of LGBT or homosexuality continues to increase. Government agencies, religious organizations, and institutional bodies also expressed disagreement in the existence of LGBT in Indonesia. Here is the rejection of data from agencies and community groups and religious leaders. 
Table 1.1

List of Disapprovals to LGBT

\begin{tabular}{|l|l|l|}
\hline Year & \multicolumn{1}{|c|}{ Institution } & \multicolumn{1}{|c|}{ Form of Rejection } \\
\hline 2008 & $\begin{array}{l}\text { Gereja Katolik } \\
\text { Roma }\end{array}$ & $\begin{array}{l}\text { Issuing an expression of opposition to the state } \\
\text { MA of California that allows for marriage of } \\
\text { the type }\end{array}$ \\
\hline 2014 & MUI & $\begin{array}{l}\text { Issuing Fatwa MUI no. 57, 2014 on lesbian, } \\
\text { gay, sodomy and obscenity. }\end{array}$ \\
\hline 2015 & MUI & $\begin{array}{l}\text { Issued a stern warning and recommended death } \\
\text { penalty for lesbian, gay and sodomy } \\
\text { perpetrators }\end{array}$ \\
\hline 2016 & FPI & $\begin{array}{l}\text { Doing LGBT sweeping on boarding house in } \\
\text { Bandung }\end{array}$ \\
\hline 2016 & MUI & $\begin{array}{l}\text { MUI affirmed rejecting any form of } \\
\text { propaganda, promotion, and support to LGBT } \\
\text { in Indonesia }\end{array}$ \\
\hline 2016 & $\begin{array}{l}\text { KWI, MUI, } \\
\text { Walubi, Matakin }\end{array}$ & $\begin{array}{l}\text { Oppose the legalization of LGBT in Indonesia, } \\
\text { because it is not in accordance with the } \\
\text { teachings of Religion and government } \\
\text { regulations }\end{array}$ \\
\hline 2016 & PBNU & $\begin{array}{l}\text { Resisting explicitly the movements and } \\
\text { allowing or acknowledging the existence of } \\
\text { LGBT }\end{array}$ \\
\hline 2016 & PBNU & $\begin{array}{l}\text { Fenomena LGBT di Indonesia sudah sangat } \\
\text { berbahaya }\end{array}$ \\
\hline
\end{tabular}

Resource : Rappler.com

The rejection of homosexuals or LGBT does not only occur in the layers of religious groups or institutions, but from the direct layers of society who expressly reject the existence of LGBT in Indonesia, the rejection is done in various forms, from demonstrations directly even by gathering the masses in the form petitions to deny the existence of LGBT or homosexuals in Indonesia, Refusals in the form of petitions filled by various levels of society in Indonesia each year have increased.

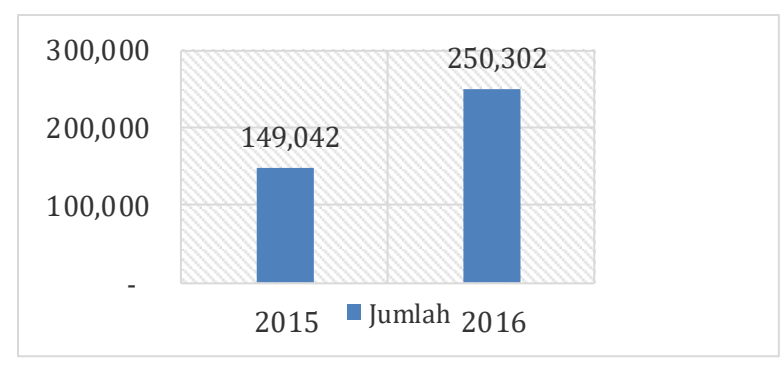

Source : Petisionline.net

Figure 1.1

Number of LGBT refusal petitions

In the midst of increasing resistance to the existence of LGBT in Indonesia, the number of homosexual or LGBT tendencies has increased significantly. According to the Indonesian Ministry of Social Affairs LGBT population in Indonesia is the 5th largest in the world, after China, India, Europe and America, even in the United States 
Facebook users who publicly stated that they LGBT amounted to 26 million, while in Indonesia 6 million Facebook users do the same thing.

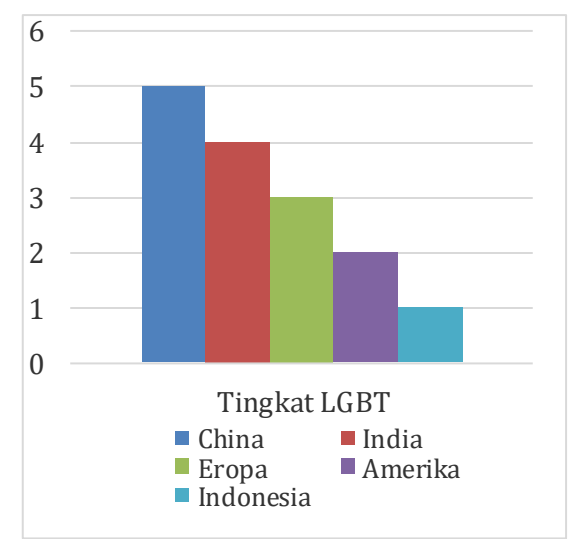

Source : Ministry of Social Affairs of Indonesia Figure 1.2 The ranking of LGBT populations in the World

Data from the Ministry of Health show significant developmental data, from the year 2012 showed data 1.095.970 people have homosexual tendencies, and increased about 400,000 people each year.

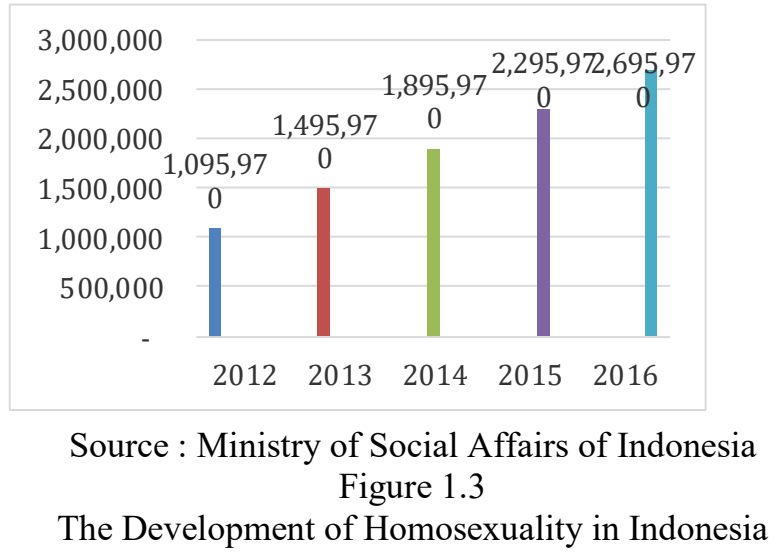

From these data can be seen increasingly widespread homosexual trends in Indonesia that worries many people, including the government itself. More and more resistance from year to year from various parties, but the movement of homosexuals is increasing. According Chaerunnisa, (2008) In the last five years social environment factors have been more affecting homosexual behavior from career or occupation, community of people who joined certain clubs and followed by traumatic events. While some researchers believe that homosexuality is a result of childhood experiences, especially the interaction between children and parents. The facts found show that homosexuality is due to the influence of dominant mothers and passive fathers (Carlson, 1994: 312). While Nugroho, Siswati, \& Sakti (2012) share the factors causing individuals to be homosexual as follows: (1) Causes factor is divided into biological and environmental factors. Biological factors still can not be ascertained as one cause of same-sex sexual orientation. The environment has greater influence than biological factors; (2) Environmental factors then subdivided into family environment and social environment. Parenting patterns that tend to be authoritarian and use more violence to punish children affect the child's personality; (3) Early homosexual experience also has an influence on the formation of identity on gay, the existence of sexual experience of same-sex give pleasure to the subject that want to repeat again. Early homosexual experiences that occur over and over again can make the subject end up enjoying same-sex relationships. 
Based on the phenomenon, researchers formulate research questions as follows: "What factors that predominantly affect a person's tendency to be gay? Does the role of government be a significant variable affecting the tendency of being gay? ". To answer the research question, the purpose of this research are:

1. To analyze patterns of gay respondents' behavior

2. To analyze the influence of parenting patterns, childhood sexual violence trauma and personal knowledge of tendencies behaving gay

3. To analyze the influence of the role of social agents and government intervention on gay behavioral tendencies

\section{LITERATURE REVIEW}

1. Social Marketing

Social marketing is a set of processes that use marketing and disciplinary principles that have a positive impact on social issues in health, injury prevention, the environment and public involvement. This principle is used to help reduce the risk of diabetes, stop the spread of HIV / AIDS, prevent malaria, decrease waste disposal, help reduce tobacco abuse, reduce infant mortality and many more related to the social and even health. (Lee \& Kotler, 2011)

The same thing also expressed Kotler (2016) that defines social marketing as an effort / public relations strategy to change attitudes and behavior of audiences in order to overcome various social problems. And also an application of marketing concepts on non-commercial activities related to community awareness, people's welfare and social services. Ordinary social marketing is also called another call social campaign.

\section{Social Agent}

Living things in this world require interaction with individuals with other individuals. If animals interact with different sex animals related only because it is caused by instinct, then humans have other habits to interact with each other. Habits possessed by humans vary, can be in the field of economy, kinship, education, religion, politics, and others that must be learned by each new member in a society through a process called socialization.

Berger (2004) defines socialization as the process by which a child learns to become a participating member of society. According to Berger, socialization studies a number of roles. Therefore, the theory of socialization according to a number of sociological figures is a theory about the role. The agents of socialization are the parties who carry out the socialization. Fuller and Jacobs (2004) identified four major socialization agencies: (1) Family: consisting of parents and siblings commonly called nuclear families, usually consisting of father, mother, siblings or other relatives who lived in one house for a long time. Socialization agents can be more numerous, such as the role of grandparents, grandmothers, uncles and aunt who are in good bond with the outgoing of the father or mother (Extended Family). Jaeger (2004) suggests that the role of socialization agencies at this early stage, especially the elderly, is very important.

The second socializing agent is a Playmate. Once you start traveling, and begin to grow large a child gets another socializing agency: a playmate. It is at this stage that a child enters a stage game (learning the rules that govern equal roles in a playgroup where a child begins to learn the values of justice). If in the family they only interact with older people or adults, in this group they tend to find new things with playmates. Santrock (2007) says that the most important role of peers is: a). As a source of information about the world outside the family; b) Cognitive sources, for problem solving and knowledge acquisition; c) Emotional sources, to express expression and identity. Through interaction with peers, children and youth learn the mode of mutual relationship symmetrically. For some youths, the experience of being denied or ignored can make them feel lonely and hostile.

The third social agency of the formal education system School. Here someone learns new things he has not learned in family or play groups. Formal education prepares for the mastery of new roles in the future, when someone is not dependent again with his parents. A number of sociologists focus their attention on the differences between socialization in the family and the socialization of the formal education system. Dreeben (2004) argues that what children learn in school besides reading, writing and counting is about independence, achievement, universalism, and specifity. In school children should learn independently, if at home children can rely on their parents to help do things at home, then in school most of the schoolwork must be done by each individual with their own responsibility. From the view of Dreeben (2004) we can see that the school is a transitional place between family and society. Schools introduce a new rule for members of the community, and sometimes the new rules contradict the rules that have been learned during the socialization of the child at home. 
The next social agent is Mass Media. Mass media is one of the main instruments or tools in shaping the gender constructs of society. Mass media have characteristics with a wide reach, can be an effective tool in disseminating construction and the foundation of gender to the community. In recent years, the mass media is growing rapidly with the existence of various social networks like Facebook, Twitter, Instagram, Path, Line, Google + , Linkedin, Youtube, and others. Social networking sites which are a service-based web that allows users to create profiles, view the list of available users, and invite or accept friends to join the site. The basic view of this social networking site displays the user profile page, which contains the user identity and photos. Both printed and electronic media such as social networking influence the value of some people. The changed values include language, behavior, other views on one gender, dominating attitude and discrimination, and so on. In terms of language, based on research conducted by Palmer (2015) states that men more often use language that connotes inclusive like sexism when making status than women. In terms of behavior many of the more male male media managers will produce products that tend to favor the interests of men, and despite the coverage of women, the tendency that comes with commercial interest alone.

Light, Keller and Calhoun (2004) suggests that mass media consisting of print media (newspapers, magazines) and electronics (radio, TV, film, internet) is a form of communication that reaches a large number of people. Mass media is identified as a socialization agent that also influences the behavior of its audience. Improved technology that enables the improvement of message quality and increased frequency of community application also provides an opportunity for mass media to act as an agent of socialization, which is increasingly important. awareness of the importance of mass media for socialization has also encouraged educators to take advantage of mass media.

\section{Government Intervention}

Intervention is interpreted to interfere in a dispute between two parties, may be in the form of people, class, State and so on. While the Government is a system of exercising the powers and powers governing the social, economic, and political life of a country or its parts. It is also defined that a group of people who share the same limited responsibility for using power. In terms of such intervention the government has a basis for what is the responsibility of the government, namely the function of the government itself. The government has two basic functions: 1) Primary function or service function is the primary function or service function that is government function as non-privatized public service provider including security services, civil service / public service and bureaucracy; 2) Secondary function or empowerment function is a secondary function or function of empowerment that is as a provider of needs and demands that are governed by goods and services that they can not afford to fulfill themselves because it is still weak and helpless, including the provision and construction of facilities and infrastructure. Government intervention in the case of homosexual treatment will be more emphasized from the primary government function or service function in which public services are based in the function of government services conducted through social campaigns.

According to Law no. 25 Year 2009 on Public Service that the implementation of public services should be based on: 1) Public interest is the interest of the people who to access it, does not require a certain burden. Interests that should take precedence over other interests while keeping in mind the important proportions and still respect other interests; 2) Legal certainty Implementation of public services can be completed within the specified time frame.

\section{Personal Knowledge}

According to Notoatmodjo (2010) knowledge is the result of human sensing, or the result of knowing a person to the object through his or her senses (eyes, nose, ears, etc.). By itself, at the time of sensing to produce such knowledge is greatly influenced by the intensity of attention and perception of the object. Much of a person's knowledge is acquired through the sense of sight (eye). A person's knowledge of objects has different intensities or levels. Broadly divided into 6 levels of knowledge, namely: a) Know (know): is defined only as a recall (call) a memory that has been there before after observing something; b) Understanding (comprehension): Understanding an object rather than simply knowing the object, not just to mention, but the person must be able to interpret correctly about the known object; c) Application (application) defined if the person who has understood the object in question can use or apply the known principle to another situation; d) Analysis (analysis) is a person's ability to describe and / or separate, then looking for a relationship between the components contained in a known problem or object. The indication that one's knowledge has reached the level of analysis is that if the person has been able to distinguish, or segregate, classify, draw diagrams (diagrams) of knowledge of the object; e) Synthesis: indicates a person's ability to encapsulate, analyze or put in a logical relationship of the components of knowledge possessed; f) Evaluation: Evaluation relates to a person's ability to 
justify or judge a particular object. This judgment is by itself based on a self-determined criterion or norms prevailing in society.

\section{Parenting Patterns}

According to Ki Hajar Dewantoro as quoted Shochib (1998) states that "Family is the center of education first and foremost, because since the emergence of human civilization until now the family always affect the growth of man's character every man". The definition of family can be viewed from the dimensions of blood relations and social relationships. because in the dimension of the relationship of blood is a unity that is bound by blood relations between one another. Based on the dimensions of this blood relationship, the family can be divided into large families and nuclear families. The family is the most important primary group in society. While in the dimension of social relationships, the family is a unity that is bound by the interconnection or interaction and mutual influence between one another, although among them there is no blood relation.

Based on Baumrind (Martinez and Garcia, 2007) parenting patterns are divided into four kinds: 1) Authoritative: a parenting pattern with demandingness and responsiveness. The characteristic of Baumrind's authoritative parenting (Casmini, 2007) is to be warm but firm, set the standards for carrying it out and giving a consistent expectation of the needs and abilities of the child, giving children the opportunity to develop autonomy and be self-directed, responsibility for his behavior, and, facing children rationally, orientation to problems encourages family discussions and explains the discipline they provide; 2) Indulgent: the parenting pattern is low on demandingness but high in responsiveness. The hallmark of indulgent parenting according to Baumrind (Casmini, 2007: 50) is to accept his son and be more passive in disciplinary issues, to demand very little of his children, to give his children freedom to act unrestrictedly and prefer to consider themselves as a center for their children. his child, regardless of whether his son considers it or not; 3) Authoritarian, the parenting pattern is demandingness but low responsiveness. Authoritarian parenting characteristic according to Baumrind (Casmini, 2007 ) is to give high value to compliance and fulfilled his request, tend to prefer to punish, is absolute and full of discipline, parents ask their children to accept everything without question, rules and standards are still given by parents and they do not encourage the child's behavior freely and restrict the child; 4) Neglectful: the parenting pattern is low in demandingness or responsiveness. Neglectful parenting features are the same thing.

6. Sexual violence in childhood

The beginning of the term acts of violence in children or child abuse and neglect is known from the world of medicine. Around 1946, Caffey-a radiologist reported cases of clinical injuries such as multiplefractures in infants or infants with uncreated unbounded subdural haemorrhage. In the medical world, this term is known as Caffey Syndrome (Ranuh, 1999).

Barker (in Huraerah, 2007) defines child abuse as repeatedly physical and emotional abuse of dependent children, through the urge of desire, uncontrolled body punishment, permanent degradation and scorn or sexual violence. Sexual violence is a form of sexual contact or other form of sexual unwantedness. Sexual violence is usually accompanied by psychological or physical stress (O'Barnett et al., In Matlin, 2008). Rape is a specific type of sexual violence. Rape can be defined as sexual penetration without permission or by coercion, accompanied by physical violence (Tobach, in Matlin, 2008). Lawson (in Huraerah, 2007), an international psychiatrist who formulates the definition of child abuse, mentions four kinds of abuse, emotional abuse, verbal abuse, physical abuse, and sexual abuse.

\section{Decision / behavioral tendencies}

According to Huber in Eunuch (1995: 5) the decision-making process begins when a problem is explored and ends when an alternative decision is selected. Sumaryanto in Terry (2012) states that in order to develop the ability to make decisions, it takes some provision to do so. Janis \& Mann in Tuapattinaya and Hartati (2014) stated that in general individuals will face conflict in taking a very important decision. The emergence of conflict makes decision makers very careful in making decisions to deal with risks that will arise. These problems will also affect the individual to accept or reject the action to be performed in accordance with the decision made. Attitude that will appear usually is doubt, uncertainty, uncertainty, and signs of stress when the decision has been determined. Based on the description, the method that is considered effective in making the decision is the method using conflict-theory model.

This method is considered able to see all the consequences that may occur when a decision is made. The basis of this approach is 4 questions that will be answered by the decision maker. The questions are:

1) Is there a serious risk if I do not make changes?

2) Is there a serious risk if I make a change?

3) Is there any hope of finding a good and satisfactory solution? 
4) Is it enough time to achieve it calmly and unhurriedly?

The decision-making process basically consists of several steps. Janis \& Mann (2013) describes 5 processes through which individuals make decisions: 1) Assessing Problems / Information: problems can be said to be conflicts that occur in real situations with other situations being targeted by the invidual. In other words the problem can be identified by the individual as he is aware of the gap between the real situation and the expected. Problems require individuals to take new action; 2) Surveying the alternative: after getting a good understanding of the problem faced, the individual usually rethink the actions he or she normally does. However, when the action is deemed inappropriate, the individual begins to focus on some alternative options, the individual will seek information or seek input from others who he deems more competent in overcoming the problems at hand; 3) Considering Alternatives: individuals begin to consider the advantages and disadvantages of each alternative option. Consideration of risk also becomes the basis of comparison of each alternative choice. Usually the individual will pay attention to other information that may be missed, so not infrequently individuals experience hesitation at this stage; 4) Declare Commitment: once the individual gets the solution and the right action for his problem, he begins to realize his decision in his life; 5) Preparing for negative feedback: individual decisions have been deemed appropriate, and he is confident of his decision. He must also prepare to face the possibility of negative feedback. In making decisions, the process is sometimes not always sequential. There are also nonconsecutive decision-making. There are times when individuals make decisions with a fast process. In this case, it can pass one or two stages at a time. By Janis Mann this is called reversion. The five stages of decision making proposed by Janis \& Mann in Tuapattinaya and Hartati (2014) will show a unique process of each stage. Processes that occur from one stage to the next will illustrate the negative and positive side that may occur from each answer option.

\section{RESEARCH METHOD}

This research is aimed to explain the influence of variables through hypothesis testing. The population is all person who indicated gay behavior which are located in Jakarta. Sampling was carried out proportionally which is 220 (5 x 44) people who indicated gay behavior who live in some areas in Jakarta. The variables used in this study consisted of 6 variables: parenting pattern (X1), childhood sexual violence trauma (X2), personal knowledge (X3), social agents role (X4), government interventions (X5) as exogenous, and gay tendencies (Y1) as an endogenous variable.

Primary data was collected by questionnaire. Mechanical delivery of questionnaires delivered directly to the respondents by enumarator who will explain how to fill out the questionnaire. This technique is expected to reduce the differences in interpretation between respondents with investigators. Data were processed by using Structural Equation Model (SEM) with LISREL program package version 8.5. The use of SEM is done because it enables researchers to test the relationship between the complex variables to obtain overall picture of the overall models. The results of criteria of suitability test are summarized in Table 1.

Table 1. Criteria of Suitability Test

\begin{tabular}{|l|l|l|}
\hline No. & Goodness of Fit Index & Cut-off Value \\
\hline 1. & Significant Probability & $>0.05$ \\
\hline Absolute Fit Measure & \\
\hline 2. & X2 Chi-Square & Diharapkan kecil \\
\hline 3. & RMSEA & $<0.08$ \\
\hline 4. & GFI & $>0.90$ \\
\hline Incremental Fit Measure & $>0.95$ \\
\hline $5 . \quad$ & TLI & $>0.95$ \\
\hline 6. & CFI \\
\hline Parsimonius Fit Measures & $>0.90$ \\
\hline 7. & AGFI & $>2.00$ \\
\hline 8. & CMIN/DF \\
\hline \multicolumn{2}{|l|}{ Source: Ferdinand (2006:92) } \\
\hline
\end{tabular}

Based on Table 1, criteria Goodness-of-Fit measure the suitability of observation or actual input (covariance or correlation matrix) with the predictions of the model proposed (proposed model). There are three types of measures Goodness-of-Fit that will be used in this study. 


\section{RESULTS AND DISCUSSION}

In the research conducted, the authors propose a set of questionnaires to the respondents of 220 people. The questionnaire consists of a number of questions that represent the 6 variables studied. The six research instruments in the form of questionnaires are instruments on parenting patern, childhood sexual violence trauma, personal knowledge, social agents role and government intervention. Before analyzed the instrument tested in advance by using the validity and reliability test. Confirmatory factor analysis is performed to test concepts constructed using several measurable indicators. From data processing got result that all dimension forming indicator of each variable have validity test value done using confirmatory analysis. In the confirmatory analysis, the latent variable is considered as the underlying cause variable of its indicators. The basis of decision making this validity test is if the Loading factor $\geq 0.5$ then the item is said to be valid.

Goodness of Fit test results that have been done got the following results:

Table 4.1

Confirmatory Test Results

\begin{tabular}{|c|l|c|c|c|}
\hline No. & \multicolumn{1}{|c|}{ Ukuran GOF } & $\begin{array}{c}\text { Tingkat Target } \\
\text { Kecocokan }\end{array}$ & $\begin{array}{c}\text { Hasil } \\
\text { Estimasi }\end{array}$ & $\begin{array}{c}\text { Tingkat } \\
\text { Kecocokan }\end{array}$ \\
\hline 1 & $\begin{array}{l}\text { Root Mean Square Error of Appoximation } \\
\text { (RMSEA) P (close Fit) }\end{array}$ & $\begin{array}{c}\text { RMSEA } \leq 0,08 \\
\geq 20,50\end{array}$ & 0,076 & Good Fit \\
\hline 2 & Normed Fit Index(NFI) & NFI $\geq 0,90$ & 0,84 & Marginal Fit \\
\hline 3 & Non-Noormed Fit Index (NNFI) & NNFI $\geq 0,90$ & 0,89 & Marginal Fit \\
\hline 4 & Comparative Fit Index (CFI) & $\mathrm{CFI} \geq 0,90$ & 0,90 & Marginal Fit \\
\hline 5 & Incremental Fit Index (IFI) & $\mathrm{IFI} \geq 0,90$ & 0,90 & Marginal Fit \\
\hline 6 & Relative Fit Index (RFI) & $\mathrm{RFI} \geq 0,90$ & 0,82 & Marginal Fit \\
\hline 7 & Goodnees of Fit Index (GFI) & $\mathrm{GFI} \geq 0,90$ & 0,78 & Marginal Fit \\
\hline 8 & Adjusted Goodness of Fit Index (AGFI) & $\mathrm{AGFI} \geq 0,90$ & 0,74 & Marginal Fit \\
\hline
\end{tabular}

In this study there are five hypotheses to be tested, the test is done by looking at the significance of each variable relationship. The significance value used is 0.05 or $5 \%$ with the value $-t \geq 1.96$ (Wijayanto, 2008). If the value $t$ is between -1.96 and $1.96(-1.96 \geq t \geq 1.96)$ then it states that the hypothesis is rejected, whereas the value of $t$ is greater than $1.96(\mathrm{t} \geq 1.96)$ or less than $-1.96(\mathrm{t} \leq-1.96)$ then the hypothesis is accepted.



Figure 4.2. Structural Research Models 


\begin{tabular}{|c|c|c|c|c|}
\hline Hypothesis & $\begin{array}{l}\text { Structural } \\
\text { Path }\end{array}$ & T-Values & Explanation & Conclusion \\
\hline H1 & $\begin{array}{l}\text { Parenting } \\
\text { Patterns } \rightarrow \\
\text { gay } \\
\text { tendencies }\end{array}$ & 1.04 & $\begin{array}{l}\text { The data do } \\
\text { not support } \\
\text { the hypothesis }\end{array}$ & $\begin{array}{c}\text { Parenting } \\
\text { Patterns has no } \\
\text { effect on gay } \\
\text { tendencies }\end{array}$ \\
\hline H2 & $\begin{array}{l}\text { Sexual } \\
\text { Violence } \rightarrow \\
\text { gay } \\
\text { tendencies }\end{array}$ & 1.82 & $\begin{array}{l}\text { The data do } \\
\text { not support } \\
\text { the hypothesis }\end{array}$ & $\begin{array}{c}\text { Sexual } \\
\text { Violence no } \\
\text { effect gay } \\
\text { tendencies }\end{array}$ \\
\hline H3 & $\begin{array}{l}\text { Personal } \\
\text { Knowledge } \\
\rightarrow \text { gay } \\
\text { tendencies }\end{array}$ & 6.60 & Significant & $\begin{array}{l}\text { Personal } \\
\text { Knowledge } \\
\text { effect on gay } \\
\text { tendencies }\end{array}$ \\
\hline H4 & $\begin{array}{l}\text { Social Agents } \\
\text { role } \rightarrow \text { gay } \\
\text { tendencies }\end{array}$ & 2.93 & Significant & $\begin{array}{c}\text { Social Agents } \\
\text { effect on gay } \\
\text { tendencies }\end{array}$ \\
\hline H5 & $\begin{array}{l}\text { Government } \\
\text { Intervention } \\
\rightarrow \text { gay } \\
\text { tendencies }\end{array}$ & -0.25 & Significant & $\begin{array}{l}\text { Government } \\
\text { Intervention } \\
\text { no effect on } \\
\text { gay tendencies }\end{array}$ \\
\hline
\end{tabular}

From the result of statistical test of parenting patterns variable has no significant effect on gay tendencies because it has t-values value below 1.96 that is 1.04 . The sexual violence variable also does not affect to gay tendencies variable it has the value of t-value below 1.96 that is 1.82 . While the personal knowledge variable has a significant effect on the gay tendencies because it has the value of t-value above 1.96 is 6.60. Social agents role also has significant effect on gay tendencies because it has value above 1.96 that is 2.93. However, government intervention also have no significant effect on gay tendencies because they have t-values below 1.96 ie -0.25 .

\section{CONCLUSION}

The purpose of this study was to analyze the effects of parenting patterns, the trauma of sexual violence in childhood, personal knowledge, the role of social agents and government intervention on gay behavioral tendencies.

The results showed that personal knowledge and the role of social agents had a significant and positive influence on gay tendencies. While parenting patterns, childhood sexual violence trauma and government intervention have no significant effect on gay behavioral tendencies. This means that the tendency of gay behavior is more due to a person's knowledge of the good and bad behavior, and the role of social agents such as parents, friends in the neighborhood, public figures, celebrities, and other social agents.

This is in line with research conducted by Nugroho et al (2015) in explaining that decision making to homosexuals in early adult males in influencing one's knowledge and the depth of a person in homosexual, even to the experience of the person. And also in line with the theory of Notoatmodjo (2010) where knowledge is the sensation of certain objects and perceptions that cause a person to have the intensity and level of different knowledge. The results of this study are confirmed by the results of this study, as the results agree most at the questionnaire stating "I can remember information about homosexuals". This means that knowledge of homosexuals becomes a factor that influences a person to become homosexual.

These are important for the development of social marketing in the context of the role of government as regulators to prevent the growing number of sexual deviations in this case gay in Indonesia. 
Things to suggest are:

1. Prevent the dissemination of knowledge, information as well as the deeper things about homosexuality, because the more people have knowledge about homosexuals the more people can have homosexual tendencies or can more tolerate the existence of homosexuals in Indonesia, therefore with the aim to suppress the number of homosexual tendencies are expected to closing deeper information about homosexuality.

2. Appeal to a social agent to keep each other's family members, friends from falling into sexual deviations, and not be an example of a sexual perversion

\section{REFERENCESS}

Abdul Rahman, Agus. 2013. Social Psychology: Knowledge Integration of Revelation and Empirical Knowledge Jakarta: Rajawali Pers.

Azhar, Kasim. (1995). Decision Making Theory. Jakarta : Fakultas Ekonomi Universitas Indonesia.

Baumrind, D. (1997). Child-care pratices anteceding three patterns of preschool behavior. Genetic Psychology Monographs, 75.

Berger, R. M., \& Mallo D. (1993). “Social Support Networks of Gay Men”. Journal of Sociology $\&$ Social Welfare, 20(1), 155-161.

Ministry of Education. (2008). Indonesia Dictionary.Jakarta: PT. Gramedia Pustaka Utama

Dirgayuza, S. (2009). A practical guide to optimize facebook. Jakata: Media Kita.

Feldman, R.S. (2012). Introduction to Psychology: Understanding Psychology edition 10.Jakarta: Salemba Humanika.

Fuller, J.S dan Jacobs, J. (1973). Socialization Jack D. Douglas (ed). Introduction to Sociology : Situations and Structures. New York: The Free Press.

Ghozali, Imam. (2009). Application of Multivariate Analysis With SPSS Semarang Program: Diponegoro University Publishing Agency.

Ilham, A. (2011). "Interpersonal Communication Pattern of Homosexuals to Their Community in Serang City". Journal of the University of Sultan Ageng Tirtayasa.

Janis, I. \& Mann. (1977). Decision Making A Psycological Analysis Of Conflict, Choice, and Commitment. New York: The Free Press.

Jose, P. E., Alexandra, M., Rafael, B. (2012). “Autoconcepto, Ansiedad social y sintomatología depresiva en adolescentes Españoles según su orientación sexual”. Journal of Ansiedad y Estrés.

Kotler, Philip. and Lee, Nancy. (2011). Social Marketing: Influencing Behaviour for Good. California: SAGE Publication, Inc.

Lawson R.Wulsin and Arthur J, BarskyVictor RG, Kaplan NM. (2007). Systemic hypertension: mechanisms and diagnosis. In: Libby P, Bonow RO, Mann DL, Zipes DP, eds.,. Braunwald's Heart Disease: A Textbook of Cardiovascular Medicine. 8th ed. Philadelphia, Pa; Saunders Elsevier: chap 86.

Matlin, Margareth W. (2008). The psychology of woman. (6th ed.). United State of America: Thomson Wardsworth.

Ndraha, Talizi. 2012. Introduction to Human Resource Development Theory, cet- 2. Jakarta: Rineka Cipta.

Notoarmodjo, Soekidjo. (2010). Health Promotion Theory and Applications. Jakarta:

Rineka Cipta.

Nugroho, S. C.,Siswati, Dra. Msi, \& Sakti, Dra. H. M.Kes. (2012) Decision Making Being Homosexual in Early Adult Age Men, 11.

Olivia, S T. (2012). "Differences Process Coming out between Gay and Lesbian ". Journal Psychology of Bina Nusantara University.

Palmer, A. (2005). High blood pressure. Alih bahasa: Elizabeth Yasmine. Jakarta: Erlangga.

Prasetyo, Bambang. 2007. Quantitative Research Methodology.Jakarta : PT. Raja Grafindo Persada

Pudjiastuti, Wahyuni. (2016). Social Marketing. Jakarta: Yayasan Obor Indonesia.

Ranuh, I.G.N.(1999). Weakness in Child Abuse Case Recording and How to Overcome it. Yogyakarta.

Sadarjoen, S. S. (2005). Psychosexual Disorder Cases. Bandung: Refika Aditama. Santrock, J. (2007). Remaja. Jakarta: Erlangga.

Santrock, J.W. (2007). Educational Psychology (second edition). (Penerj. Tri Wibowo B.S). Jakarta: Kencana.

Shochib, Moh. (2010). Parenting Pattern (In Helping Children Develop Self Discipline). Jakarta: PT Rineka Cipta

Sitinjak, Tumpal. J. R dan Sugiarto. (2006). LISREL. Jakarta: Graha Ilmu

Sugiyono. (2012). Business Research Methods (Quantitative Approach, Qualitative, and R \& D). Bandung: Alfabeata. 
Sugiyono. (2014). Quantitative, Qualitative, and Combinative Research Methods (Mixed Methods). Bandung: Alfabeta.

Sumaryanto. (2012). Sport in the Axiological Perspective and its Relevance for the Development of the Nation's Character. Yogyakarta

Sunarto, Kamanto. (2004). Introduction to Sociology. Jakarta: Lembaga Penerbit Fakultas Ekonomi Universitas Indonesia.

Tower, Cynthia Crosson. (2002). Child Abuse and neglect. USA: Mc Graw Hill.

Tommy, Pranata Dwi. (2015). Social Behavior and Reality Gay Life in Samarinda City. Jurnal Psikologi . Fakultas Ilmu Sosial dan Ilmu Politik. Universitas Mulawarman

Tuapattinaya. Y. I., \& Hartati, S. (2014). "Decision Making To Marry Different Ethnicity: Phenomenological Studies In Javanese Women "Jurnal Psikologi Undip, 13(1), 34-41.

Law no. 25 Year 2009 on Public Service. 